\title{
Empleo racional de la coronectomía en la extracción de terceros molares incluidos
}

\section{Rational application of coronectomy when treating lower impacted third molar}

C. Recio Lora', D. Torres Lagares²; M. de Maeztu Martínez ; M.M. Romero Ruiz'; J.L.Gutiérrez Pérez

Resumen: Los terceros molares son los dientes que, con más frecuencia, sufren el fracaso de su erupción y quedan incluidos o retenidos dentro de los maxilares. Un gran porcentaje de nuestros pacientes presentan los cordales incluidos y, de ellos, una parte importante se acompaña de patología que hace aconsejable su tratamiento quirúrgico. La técnica de la coronectomía aplicada al tercer molar incluido fue descrita por primera vez por Ecuyer y Debien en 1984 como la eliminación parcial de dicho diente, dejando deliberadamente parte de su raíz en el interior de la mandíbula. Fue propuesta para evitar la lesión del nervio dentario inferior (NDI) en aquéllos casos en los que existía una íntima relación entre ambas estructuras anatómicas. Aunque el objetivo de la técnica es muy claro, no está libre de controversia, ya que el cirujano debe valorar la posibilidad de una complicación infecciosa de origen pulpar. Presentamos un caso clínico exitoso de esta técnica, junto al análisis de la postura ante la técnica de los distintos autores, así como sus ventajas e inconvenientes.

Palabras clave: Tercer molar incluido; Extracción dentaria; Lesión nerviosa; Coronectomía.

Recibido: 28.08.2007

Aceptado: 16.03.2009

\begin{abstract}
Third molars are the teeth that most frequently fail to erupt and remain impacted or retained inside the bone. A large percentage of our patients have impacted wisdom teeth and many of these patients also have pathologies that require surgical treatment. Applied coronectomy technique of the impacted third molar was first described by Ecuyer and Debien in 1984. The described it as partial elimination of the tooth in question, deliberately leaving part of the root inside the bone. This was proposed to avoid injuring the inferior dental nerve in cases where there was a close relationship between the two anatomical structures. Although the objective of the procedure is very clear, it is still controversial. Therefore, the surgeon should evaluate the possibility of an infectious complication of pulpar origin. We present the successful clinical case that uses this technique, as well as an analysis of the distinct authors' opinions this technique and its advantages and disadvantages.
\end{abstract}

Key words: Impacted Third Molar; Tooth Extraction; Nervous lesion; Coronectomy

\footnotetext{
1 Profesora del Master en Cirugía Bucal. Facultad de Odontología. Universidad de Sevilla.

2 Profesor Ayudante de Cirugía Bucal. Universidad de Sevilla.

3 Doctor en Odontología. Práctica privada en Cirugía Bucal.

4 Profesor del Master de Cirugía Bucal. Universidad de Sevilla.

5 Profesor Titular Vinculado de Cirugía Bucal. Director del Master de Cirugía Bucal. Universidad de Sevilla. Jefe de Servicio de Cirugía Oral y Maxilofacial. Hospital Universitario Virgen del Rocío de Sevilla.
}

\section{Correspondencia:}

Daniel Torres Lagares

Facultad de Odontología. Universidad de Sevilla

C/ Avicena s/n. 41009 Sevilla. España

E-mail: danielt|@us.es 


\section{Introducción}

Los terceros molares son los dientes que, con más frecuencia, sufren el fracaso de su erupción y quedan incluidos o retenidos dentro de los maxilares. ${ }^{1}$ Aunque pueden permanecer asintomáticos toda la vida, la frecuencia de patología inducida por ellos es elevada, debido a su localización anatómica y a sus condiciones embriológicas singulares. ${ }^{1}$ Debido a la clínica que generan o al riesgo potencial de complicaciones infecciosas, tumorales, mecánicas o nerviosas, el proceder habitual será la extracción quirúrgica del tercer molar, ${ }^{1}$ si bien existe consenso en la literatura en que, si hay espacio suficiente, un cordal no erupcionado y asintomático debería dejarse en su ubicación, ya que no se puede predecir cuáles erupcionarán con éxito y cuáles no. Y no podemos olvidar que su extracción no es una maniobra exenta de riesgos. ${ }^{1}$

De entre las complicaciones derivadas de la extracción de un tercer molar incluido, la lesión del nervio dentario inferior (NDI) es una complicación grave que ocurre en un 3-5\% de los casos, manteniéndose de forma permanente en un 0,5-1\%. Por tanto, durante las maniobras de ostectomía, odontosección, luxación o curetaje, existe alto riesgo de provocar una lesión del mismo. ${ }^{2}$

La técnica de la coronectomía aplicada al tercer molar incluido fue descrita por primera vez por Ecuyer y Debien en 1984 como la eliminación parcial de dicho diente, dejando deliberadamente parte de su raíz en el interior de la mandíbula. Fue propuesta para evitar la lesión del NDI en aquéllos casos en los que existía una íntima relación entre ambas estructuras anatómicas. ${ }^{3}$ Aunque el objetivo de la técnica es muy claro, no está libre de controversia, ya que el cirujano debe valorar la posibilidad de una complicación infecciosa de origen pulpar. 4,5

Presentamos un caso de aplicación exitosa de la técnica de coronectomía en un tercer molar incluido. Posteriormente analizaremos la postura ante la técnica de los distintos autores a fin de aclarar en qué casos podemos considerar la coronectomía como técnica de elección para tratar un cordal incluido sintomático, después de un correcto estudio radiológico y de un análisis de sus ventajas e inconvenientes.

\section{Caso clínico}

Presentamos el caso clínico de un paciente varón de 25 años de edad que acude a consulta por episodios repetidos de dolor e inflamación en torno al tercer molar inferior izquierdo semiincluido (Fig. 1A). En la historia clínica no destacan antecedentes médicos de interés, el paciente no sigue ninguna medicación a diario, salvo antibióticos y antiinflamatorios, por el problema actual, no es fumador y se encuentra en perfectas condiciones de salud.

Después de la exploración clínica, solicitamos como primera prueba diagnóstica una ortopantomografía (Fig. 2A). En ella podemos observar cómo el cordal en cuestión (38) se halla en íntima relación con el canal del NDI, detectándose signos radiológicos determinados como indicadores claros de alto riesgo de lesión del nervio durante las maniobras de extracción Así, se observan curvaturas en las raíces, un oscurecimiento en torno a los ápices (raíz

\section{Introducción}

Third molars are the teeth that most frequently fail to erupt and remain impacted or retained inside the bone. ${ }^{1}$ Although unerrupted third molars can be asymptomatic all ones life, due to their anatomic location and singular embryological conditions, they frequently cause other pathologies.' Because of the symptoms that they produce or the potential risk of infectious, tumoral, mechanical or nerval complications, the correct procedure is third molar surgical extraction.' Even though there is consensus in the literature that, since we can not predict which teeth will successfully erupt and which will not, if there is enough space the non erupted and asymptomatic wisdom tooth should be left where it is. We can not forget that this extraction is one that involves risks. 1

Among the complications involved in the extraction of an impacted third molar, the most severe is injury of the inferior dental nerve. It occurs in 3-5\% of cases and remains permanent in $0.5-1 \%$ of cases. Therefore, during ostectomy, odontosection, dislocation or curettement procedures there is a high risk of injuring the inferior dental nerve.?

Applied coronectomy technique of an included third molar was first described b Ecuyer and Debien in 1984 as the partial elimination of the tooth deliberately leaving part of the root inside the bone. This was proposed to avoid injuring the inferior dental nerve in the cases where there was a close relationship between the two anatomical structures. ${ }^{3}$ Although the objective of the procedure is very clear it still controversial. Therefore, the surgeon should evaluate the possibility of an infectious complication of pulpar origin. 4,5

We present a case where coronectomy was successfully used on an impacted third molar. Afterward, we will analyze the opinions of various authors regarding technique in order to clarify when coronectomy can be considered the technique of choice to treat symptomatic compacted wisdom teeth, after a correct radiological study and analysis of its advantages and disadvantages.

\section{Clinical Case}

We present the clinical case of a 25 year old patient who consults the doctor because of repeated episodes of pain and inflammation near the inferior left semi impacted third molar. (Fig. 1A) The patient's medical history shows no prior medical conditions of interest and the patient is not taking regular medication aside from the antibiotics and anti inflammatory medication for his current problem, the patient is a non-smoker and in good health.

After the clinical examination our first test is a orthopantomogram (Fig. 2A). It allows us to see that the wisdom tooth in question is found in close relation to the canal of the inferior dental nerve, finding radiological signs that are clear indicators that there will be high risk of nerve injury during extraction operations. So, we see curves in roots, darkness 


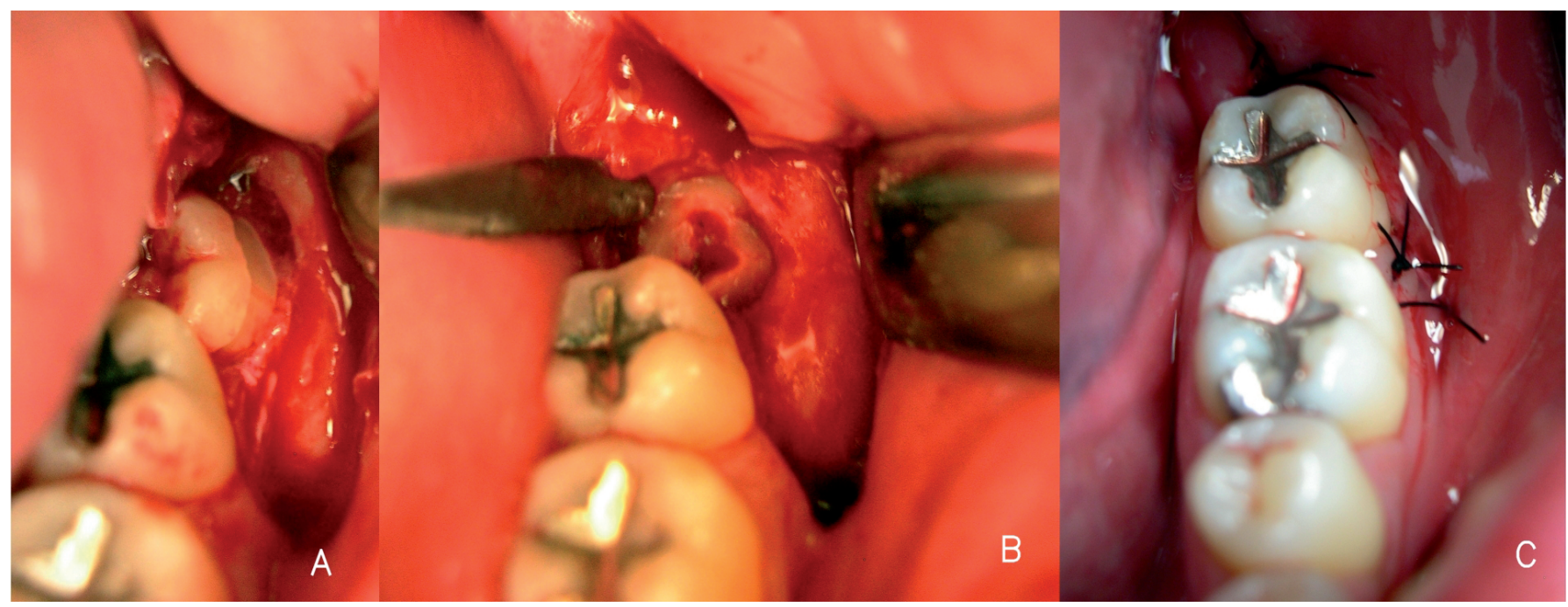

Figura 1. Imágenes intraorales de la coronectomía. A. Incisión y odontosección. B. Odontosección completada, manteniendo el fragmento radicular del cordal intraóseo. C. Sutura del colgajo.

Figure 1. Intraoral images of the coronectomy A. Incision and odontosection. B. Completed odontosection, keeping the radicular fragment of the intraosseous wisdom tooth. C. Flap Suture.

mesial) y un borramiento de la cortical superior del canal en contacto con la raíz distal.

Aunque la ortopantomografía nos mostraba una imagen bastante clara, decidimos solicitar una TC para planificar correctamente el caso antes de decidir el procedimiento terapéutico. En las imágenes de la TC verificamos que el contacto entre el cordal y el NDI es real (Figs. 2 B, C y D) y que, por tanto, el riesgo de dañarlo durante la extracción es alto.

Ante esta situación, informamos al paciente de la posibilidad de realizar una coronectomía o extracción parcial del tercer molar sintomático. Con esta técnica pretendemos eliminar la clínica causada por la pericoronaritis, ya que conseguimos un cierre directo de la herida y las raíces quedan incluidas, preservando la integridad del NDI.

El paciente fue informado de la posibilidad de una complicación infecciosa de causa pulpar, lo cual nos obligaría a reintervenir para completar la extracción. La reentrada también sería necesaria si, a largo plazo, se produjera una migración de las raíces, y éstas volvieran a generar clínica de pericoronaritis por exposición. Sólo que, si esto ocurre, probablemente la relación de las raíces con el NDI ya no sería tan clara, ni la extracción, por tanto, tan comprometida.

Después de obtener el consentimiento informado del paciente, decidimos realizar la coronectomía siguiendo la siguiente técnica quirúrgica (Figs. 1 A, B y C): Administración de profilaxis antibiótica. Realización de un incisión en bayoneta y levantamiento de un colgajo de espesor total similar al utilizado para la extracción completa de un cordal. Realización de un corte de la corona con una fresa de fisura desde la tabla vestibular, siguiendo una angulación de aproximadamente $45^{\circ}$. Esta sección es completa para no ejercer fuerza sobre las raíces con los botadores, lo cual requiere ser muy cuidadoso al aproximarnos a la tabla lingual para no lesionar el nervio lingual. Posteriormente se continúa elimi- near the apex (mesial root) and thinning of the upper cortical of the canal that touches the distal root.

Although the orthopantomogram gives us a pretty clear image we decided to take a CT in order to correctly plan the case before deciding on a therapeutic treatment. The CT images verify that there is contact between the wisdom tooth and the Inferior Dental Nerve and that due to that contact there is a high risk of damaging it during extraction.

In this situation we inform the patient of the option to carry out a coronectomy or a partial extraction of the symptomatic third molar. With this technique we try to eliminate the clinical cause which is pericoronaritis. Since we successfully closed the wound and the roots remain compacted the unity of the Inferior Dental Nerve is preserved.

The patient was informed of the possible complications including: infection caused by pulpar which would require reintervention to complete the extraction. Reintervention would also be necessary if, in the long term, the roots were to migrate and, because of their exposure, continue to create pericoronaritis. If this were to occur the relationship between the roots and the Inferior dental nerve would not be as clear and as a result the extraction would not be as clear leading to a very compromised situation.

After getting the informed consent of the patient we decide to perform coronectomy using the following surgical technique (Figs. 1 A, B and C): Administration of prophylaxis antibiotic. Making a "saddle" incision and lifting the full thickness of the flap, similar to the one used for complete wisdom tooth extraction. A cut is made in the crown with a fissure drill starting at the vestibular board and continuing at a 45 degree angle. This section is ready to have force applied on the roots with elevators: to do this it is important to be very careful not to injure the lingual nerve when we 


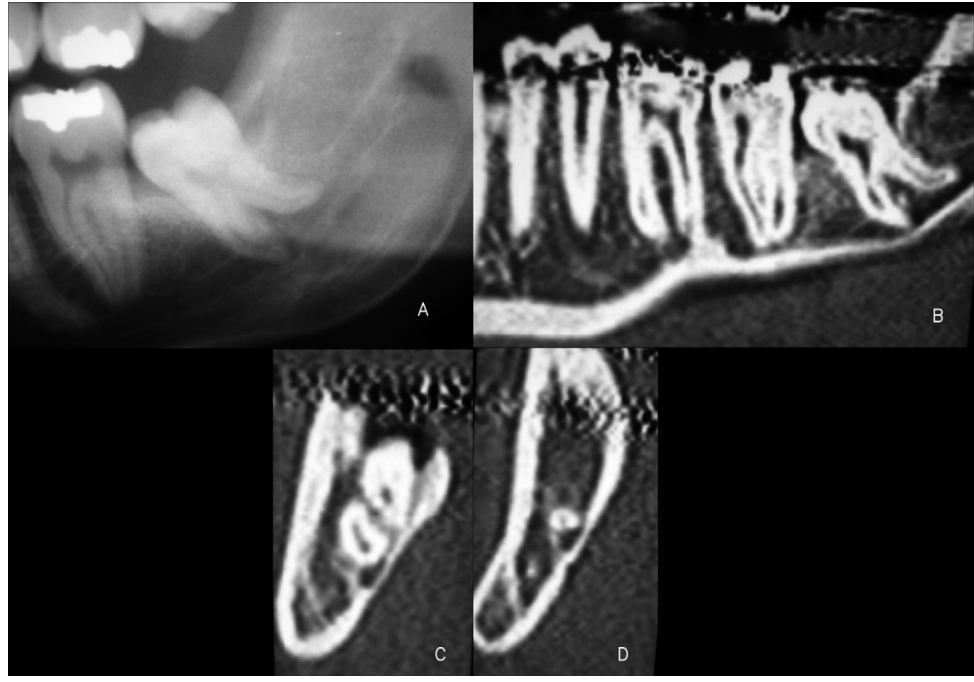

Figura 2. Estudio radiológico del caso presentado. A. Ortopantomografía. B, C y D. Tomografía computerizada (detalles) que muestran la relación del ápice del cordal con el nervio dentario inferior.

Figure 2. Radiological study of the present case. A. Orthopantomogram. B, C and $D$ - CT that shows the relationship between the wisdom tooth apex and the inferior dental nerve.

nando más tejido dentario, con la misma fresa de fisura o con una fresa redonda accediendo desde la parte superior. Esto último resulta un poco más fácil que con la fresa de fisura. De esta forma, la sección queda, al menos, $3 \mathrm{~mm}$ por debajo de las crestas óseas. Con ello se pretende facilitar que el hueso se regenere sobre las raíces y las englobe dentro de la mandíbula. No se debe tratar la superficie radicular expuesta. Finalmente se eliminan los restos de folículo, sin movilizar las raíces, el diente remanente y se sutura la herida con puntos sueltos que se retiran en una o dos semanas. Debemos realizar controles radiológicos al mes, a los seis meses (Fig. 3) y anualmente.

Todos estos pasos se llevaron a cabo en nuestro caso, y el paciente no ha presentado complicación alguna en un año tras la realización de la intervención.

\section{Discusión}

La frecuencia de lesión del nervio dentario inferior (NDI) durante la cirugía del tercer molar incluido está en torno al 3-5\%, manteniéndose la alteración nerviosa de forma permanente en un 0,5$1 \%$ de los $\operatorname{casos}^{2,6}$ Aunque no son porcentajes altos, la importancia de la lesión y las limitaciones que conlleva para el paciente le confieren gran importancia, por lo que debemos intentar evitarla en todos los casos. ${ }^{1}$

La radiografía panorámica es la prueba radiológica estándar para analizar la relación anatómica entre los terceros molares incluidos y el NDI. Varios autores coinciden en identificar una serie de signos radiológicos de alto riesgo asociados con una íntima relación entre estas dos estructuras anatómicas: ${ }^{12,14}$

1. Oscurecimiento de las raíces o imagen apical en la zona donde éstas cruzan el canal dentario.

2. Interrupción u obliteración de las corticales del canal dentario.

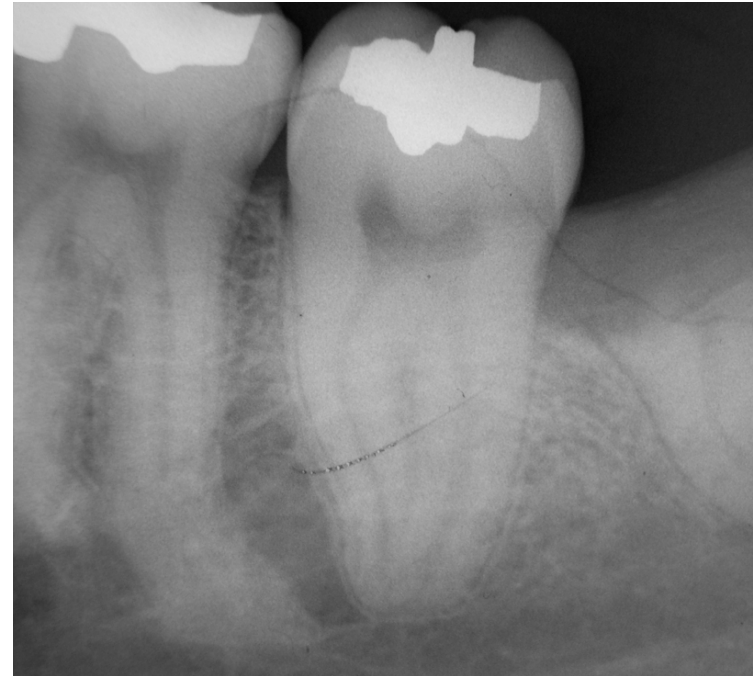

Figura 3. Radiología de control a los seis meses. No se observan alteraciones patológicas.

Figure 3. Radiological control after 6 months. There were no pathological alterations reported.

approach the lingual board. Afterwards we continue to eliminate dental tissue with the same fissure drill or with a round drill gaining access from the upper part. This can be a little easier to do with the round drill than with the fissure drill. When this is done the area is at least $3 \mathrm{~mm}$ below the bone crests. With this we try to make the bone regenerate over the roots and including them inside the mandible. The exposed radicular surface should not be treated. Finally we eliminate the follicle remnants without mobilizing the roots, the remaining tooth and the wound sutured with stitches that will fall out after a week or two. We should perform radiological controls after 1 month and again after six months (Fig. 3) and a year later.

All of these steps were carried out in our case and the patients did not show any signs of complications 1 year after the intervention.

\section{Discussion}

Incidence of inferior dental nerve damage during compacted third molar surgery is about $3-5 \%$, with permanent nerve damage in $0.5-1 \%$ of cases. ${ }^{2,6}$ Although the percentages are not very high this injury and the limitations it involves for the patient are very important, therefore we should try to avoid it in every case.?

Panoramic radiography is the standard radio graphical test to analyze the anatomical relationship between compacted third molars and the inferior dental nerve. Many authors agree that there are a series of high risk radiological signs associated with a close relationship between the two anatomic structures. ${ }^{12,14}$ : 
3. Desviación del canal dentario en la zona de contacto con las raíces.

4. Angulaciones de las raíces alrededor del canal.

5. Borramiento de las raíces que pueden suponer una perforación o ranura en el nervio.

6. Bifurcación de las raíces.

7. Borramiento del canal dentario.

8. Distancia de menos de $1 \mathrm{~mm}$ entre las raíces y la cortical superior del canal dentario.

9. Intimo contacto del canal dentario con las raíces.

10.Superposición entre ambas estructuras. ${ }^{7,8}$

Si observamos la radiografía panorámica del caso clínico presentado, vemos que coinciden varios de los signos radiológicos expuestos. Puede observarse una imagen radiolúcida en torno a los ápices del tercer molar inferior izquierdo, así como curvaturas en sus raíces en la zona del canal dentario y una difuminación de las corticales del mismo. También observamos cómo parece que existe un contacto directo entre las raíces del cordal y el canal dentario así como una superposición de imágenes, lo cual se verifica con la imagen de la TC (a la cual debemos acudir cuando existan dudas acerca de la valoración del riesgo o de la decisión terapéutica que se deba tomar). ${ }^{9,10}$

En la mayoría de los casos sintomáticos de terceros molares, éstos están semi-incluidos provocando un cuadro de pericoronaritis por la comunicación que se establece con el medio bucal; por tanto la eliminación de la corona y su tejido folicular anexo, en principio, podría resolver el problema. ${ }^{4}$

Está claro que si la extracción completa del cordal no supone riesgo de daño del NDI, ésta es la actitud terapéutica de elección,1 pero si la valoración radiológica indica riesgo elevado de parestesia tras la extracción, podríamos plantearnos la posibilidad de realizar una coronectomía. ${ }^{4}$

Aunque la coronectomía parece ser, a priori, una buena solución para estos casos comprometidos, no es una técnica libre de controversia, porque el cirujano debe plantearse cuestiones como la posibilidad de que aparezca una infección provocada por las raíces retenidas o por la sección de la pulpa.4 En respuesta a este tema existen estudios a largo plazo que demuestran que el riesgo de infección posterior es bajo. 4,11-14

Freedman, ${ }^{11}$ en 1997, presenta el seguimiento a 5 años de un caso de coronectomía publicado anteriormente (1992) y completa el estudio con 32 casos más. Sólo en un caso fue necesaria la reentrada por persistencia de la respuesta inflamatoria, el resto evolucionaron satisfactoriamente.

Pogrel y cols, ${ }^{13}$ en 2004, presentan un estudio sobre 41 pacientes con datos radiológicos de posible lesión del NDI durante la extracción de sus terceros molares incluidos. Se realizaron 50 coronectomías con un seguimiento de, al menos, 6 meses. No tuvieron lesiones del NDI en ningún caso, sí una lesión del nervio lingual, probablemente por el uso del retractor que estos autores propugnan. Un paciente tuvo que ser reintervenido de ambos cordales por fracaso de la cicatrización y persistencia de los síntomas y otro paciente por la migración de las raíces. Este fenómeno se observó en el $30 \%$ de los pacientes al cabo de los 6 meses.
1. Darkening of roots or lingual image in the area where they cross the dental canal.

2. Disruption or obliteration of the dental canal corticals.

3. Dental canal deviation in the root contact area.

4. Root angulations around the canal.

5. Root thinning that could cause a perforation or opening in the nerve.

6. Root bifurcation.

7. Thinning of the dental canal.

8. A distance of less than $1 \mathrm{~mm}$ between the roots and the upper dental canal cortical.

9. Close contact between the dental canal and the roots.

10. Overlapping of the two structures. 7,8

If we look at the panoramic radiograph of the clinical case presented we see that many of the radiological signs that we presented coincide with these signs. We could see a radio lucid image of the left inferior third molar apex, with curves in the roots in the area of the dental canal and stumping of same corticals. We also see that it looks like is direct contact between the wisdom tooth roots and the dental cavity just like an overlapping of the images. This is confirmed by the CT image (which we should refer when there are doubts about the risk involved or when making a therapeutic decision). 9,10

In the majority cases with third molar symptoms, these are semi impacted causing a quadrant of pericoronaritis. Because of the communication that is established with the buccal half; therefore elimination of the crown and its follicle tissue annex could solve the problem. ${ }^{4}$ It is clear that the complete extraction of the wisdom tooth does not involve a high risk of damaging the inferior dental nerve; this is the chosen therapeutic opinion. ${ }^{1}$ But if the radiological evaluation shows high risk of paraesthesia after extraction we would consider possibly doing a coronectomy.

Although a coronectomy seems to be a good solution in these compromised cases, its use is still controversial. The surgeon should bring up the possibility that an infection starts because of retained roots or because of the pulp section4. In response to this topic there are long term studies that show that the risk of posterior infection is low. 4,11-14

In 1997 Freedman, 11 presents a case where he follows a previously published coronectomy case for 5 years and he completes a study with 32 more cases. It was only necessary to re enter because of inflammation in one case and the rest of the patients had satisfactory progress.

In 2004 Pogrel and cols. ${ }^{13}$ did a study of 41 patients with radiological data that suggested possible injury of the inferior dental nerve during impacted third molar extraction. They carried out 50 coronectomies and at least 6 months of follow-up. There were no inferior dental nerve injuries in any of the patients. There was one lingual nerve injury, probably because of the use of a retractor chosen by the authors. One patient had to be re operated on in both wisdom teeth because of failed scarring and the persistence of symptoms. 
Renton y cols, ${ }^{14}$ en 2005 presentan un estudio sobre 128 pacientes con evidencia radiológica de relación entre sus cordales incluidos y el NDI. De la muestra, 102 cordales se extrajeron completamente y 94 se sometieron a coronectomías. De éstas, se realizaron con éxito 58 y 36 terminaron en extracción completa por movilización de las raíces durante las maniobras quirúrgicas. Tras 25 meses de seguimiento obtuvieron los siguientes datos: 19 casos de lesión del NDI en los casos de extracción completa, ninguno en los casos de coronectomías con éxito y tres casos en las coronectomías fallidas. Observaron también que se producía una migración apical de las raíces que habían quedado incluidas en el hueso mandibular y que el riesgo de infección o alveolitis no aumentaba en los casos de coronectomía.

Los resultados de estos trabajos muestran que la coronectomía es una técnica con una baja incidencia de complicaciones, aunque la migración apical de las raíces pueda considerarse como tal en los casos en los que obligue a reintervenir.

En nuestro caso clínico, tras un seguimiento de 12 meses no se han observado complicaciones infecciosas ni compromiso en la calidad de vida del paciente, aunque sí se aprecia una ligera movilización hacia crestal de las raíces. Para obtener resultados similares a los descritos, se debe hacer hincapié en una correcta selección del caso. Según Pogrel y cols., ${ }^{13}$ una coronectomía no debe realizarse en las siguientes situaciones: ${ }^{1}$

1. Dientes con infección activa, especialmente si ésta afecta a las raíces.

2. Dientes que se han movilizado durante las maniobras de extracción, ya que sus raíces podrían actuar como cuerpo extraño y favorecer la infección o migración de las mismas.

3. Dientes impactados horizontalmente a lo largo del canal dentario inferior porque la sección de la corona podría dañarlo (se aconseja emplear la coronectomía en casos de cordales verticales, mesio o distoangulados donde la sección pueda realizarse sin complicar el resultado de la técnica).

Respecto a la técnica quirúrgica, aunque algunos autores defienden la eliminación del diente hasta situarse a $2 \mathrm{~mm}$ del NDI, consideramos más prudente, tal y como describen otros colegas y hemos realizado en el caso presentado, eliminar el diente sólo lo necesario para permitir un cierre directo de la encía ( $2 \mathrm{~mm}$ por debajo del nivel óseo crestal). 4,9 Otro punto de controversia es la protección del colgajo lingual. Pogrel y cols, ${ }^{13}$ proponen realizar siempre una retracción del colgajo lingual, a pesar de que en su trabajo encuentran una complicación por parestesia lingual que ellos mismos atribuyen a la retracción del colgajo. En otros estudios han mostrado que esta maniobra por sí misma ya está comprometiendo la integridad del nervio. ${ }^{15}$ Nuestra manera de actuar en extracciones de terceros molares molares incluidos no incluye la maniobra de retracción del colgajo lingual, de ahí que en el caso clínico de coronectomía que presentamos, tampoco se haya realizado.

\section{Conclusiones}

En conclusión la coronectomía es una técnica que sólo debe utilizarse en casos en que el cirujano determine que una extracción
Another patient had to be re operated on because of root migration. After six months this phenomena was seen in $30 \%$ of the patients.

In 2005, Renton and cols. ${ }^{14}$ presented a study of 128 patients with radiological evidence related to impacted wisdom teeth and inferior dental nerve. 102 wisdom teeth in the sample were completely removed and 94 had coronectomies. 58 of which were carried out successfully and 36 ended up having the tooth removed completely because of mobilization of the roots during surgery. After 25 months of follow-up the following data was reported: in the patients who had complete extraction 19 had an Inferior dental nerve injury, none in the successful coronectomies and 3 in the cases of failed coronectomies. There was apex migration of the roots that had been left impacted in the mandible bone, and the risk of infection and alveolitis did not increase in coronectomy cases.

The results of these studies show that coronectomy is a technique that has a low incidence of complications, although apex migration of the roots could be considered as such in cases where reintervention is necessary.

In our clinical case after 12 months of follow-up we have not seen infectious complications nor compromised quality of patient life. Although, there is slight mobilization towards the crest roots.

To get results similar to the ones described we should emphasize correct selection of the case. According to Pogrel and cols. ${ }^{13}$, a coronectomy should not be performed in the following situations:

1. Infected teeth, especially if the roots are affected.

2. Teeth that have moved during extraction operations, since the roots could act as a foreign body and favor infection or migration.

3. Teeth that are horizontally impacted along the inferior dental canal because the selection of the crown could damage it (it is advised to use coronectomy in the case of vertical, mesial or distal angled wisdom teeth where the section could be carried out without complicating the results of the technique).

Regarding surgical technique although many authors defend the elimination of the tooth reaching as close as 2 $\mathrm{mm}$ from the inferior dental nerve, we think it is more tactful to eliminate only the necessary part of the tooth to allow for direct closing of the gum (2 $\mathrm{mm}$ below the bone crest $)^{4,9}$

Protecting the lingual flap is another topic of controversy. Pogrel and cols., ${ }^{13}$ suggest carrying out a simple lingual flap retraction, despite the fact that in their work they have lingual paraesthesis that they attributed to flap retraction.

Other studies have demonstrated that this procedure compromises the integrity of the nerve. ${ }^{15}$ Our way of carrying out extractions of compacted third molars does not include retraction of the lingual flap, so in coronectomy clinical case that we present we did not use that technique. 
completa del tercer molar conllevaría un riesgo importante de lesión del NDI, y siempre con el consentimiento informado del paciente. No es un procedimiento fácil, es más, requiere más destreza y perfección que la extracción completa, si bien los resultados adecuados a largo plazo publicados hacen que sea una técnica aplicable con suficientes garantías en casos bien seleccionados.

\section{Bibliografía}

1. Gutiérrez JL, Romero MM, eds. El Tercer Molar Incluido. Sevilla: GSK; 2001

2. Drage NA, Renton T. Inferior alveolar nerve injury related to mandibular third molar surgery: An unusual case presentation. Oral Surg Oral Med Oral Pathol Oral Radiol Endod. 2002;93:358-61.

3. Ecuyer J, Debien J. Deductions operatories Actual Odontoestomatol 1984;148: 695-701.

4. O'Riordan BC. Coronectomy (intentional partial odontectomy of lower third molars) Oral Surg Oral Med Oral Pathol Oral Radiol Endod. 2004;98:274-80.

5. García A. Coronectomy: a questionable procedure. J Oral Maxillofac Surg. 2005; 63:723.

6. Commissionat $\mathrm{Y}$, Roisin-Chauson $\mathrm{MH}$. Lésions du nerf alvéolaire inférieur au cours de léxtraction des dents de sagesse. Rev Stomatol Chir Maxillofac. 1995; 96:385-91.

7. Blaeser BF, August MA, Bruce R, Kaban LB, Dodson TB. Panoramic radiographic risk factors for inferior alveolar nerve injury after third molar extraction. J Oral Maxillofac Surg 2003; 61: 417-421.

8. Sedaghatfar M, August MA, Dodson TB. Panoramic radiographic findings as predictors of inferior alveolar nerve exposure following third molar extraction. J Oral Maxillofac Surg 2005;63:3-7.

9. Commissionat Y. Prévention des lesions neurologiques post-extractionelles par coronectomie de la dent de sagesse inférieure. 1 Partie. L'information dentaire 2005;33:1989-92.

10. Pawelzik J, Cohnen M, Willers R. A comparison of conventional panoramic radiographs with volumetric computed tomography images in the preoperative assessment of impacted mandibular third molars. J Oral Maxillofac Surg 2002; 60:977-8.

11. Freedman GL. Intentional partial odontectomy: Review of cases. J Oral MaxiIlofac Surg 1997;55:524-6.

12. Freedman GL. Intentional partial odontectomy: Repot of case. / Oral Maxillofac Surg 1992;50:419-21.

13. Pogrel MA, Lee JS, Muff DF. Coronectomy: A technique to protect the inferior alveolar nerve. J Oral Maxillofac Surg 2004;62:1447-52.

14. Renton T, Hankins M, Sproate $C$, McGurk M. A randomized controlled clinical trial to compare the incidence of injury to the inferior alveolar nerve as a result of coronectomy and removal of mandibular third molars. Br J Oral Maxillofac Surg 2005;43:7-12.

15. Gomes AC, Vasconcelos BC, De Oliveira ED, da Silva LC. Lingual nerve damage after mandibular third molar surgery: a randomized clinical trial. J Oral MaxiIlofac Surg. 2005;63:1443-6.

\section{Conclusions}

In conclusion, coronectomy is a technique that should only be used when the surgeon decides that complete third molar extraction would put the inferior dental nerve at great risk. The patient should always be informed and give their consent. It is not an easy procedure and it requires more skill and perfection than a complete extraction. Even though, in well selected cases, adequate long term results make it an applicable technique with sufficient guaranties. 